\title{
Carbon/nitrogen ratio as a major factor for predicting the effects of organic wastes on soil bacterial communities assessed by DNA-based molecular techniques
}

\author{
Yuan Ge $\cdot$ Chengrong Chen $\cdot$ Zhihong Xu • \\ Simon M. Eldridge $\cdot$ Kwong Yin Chan • Yan He • \\ Ji-Zheng He
}

Received: 25 February 2009 /Accepted: 13 May 2009 / Published online: 5 June 2009

(C) Springer-Verlag 2009

\begin{abstract}
Background, aim, and scope Current Australian legislation permits the beneficial application of grease trap waste (GTW) to agricultural soil, viewing it as a beneficial source of organic matter and soil conditioner containing no/low amounts of metals or pathogenic organisms. However, little is known about the influence of GTW on soil bacterial community. A field experiment was established at Menangle in south western Sydney in Australia to quantitatively assess the impacts of different types (GTW CO and GTW CL) and amounts of GTW application on the soil bacterial community and diversity. Furthermore, a municipal solid waste (MSW) compost was simultaneously examined to compare against the other organic wastes. Knowledge about the shifts in
\end{abstract}

Y. Ge $\cdot$ C. Chen $(\bowtie) \cdot \mathrm{Z} . \mathrm{Xu} \cdot \mathrm{Y}$. He

Centre for Forestry and Horticultural Research and School

of Biomolecular and Physical Sciences, Griffith University,

Nathan, Queensland 4111, Australia

e-mail: c.chen@griffith.edu.au

Y. Ge $\cdot$ J.-Z. He $(\triangle)$

Key Laboratory of Urban and Regional Ecology,

Research Centre for Eco-Environmental Sciences,

Chinese Academy of Sciences,

Beijing 100085, China

e-mail: jzhe@rcees.ac.cn

S. M. Eldridge $\cdot$ K. Y. Chan

Centre for Recycled Organics in Agriculture,

NSW Department of Primary Industries,

Richmond, NSW 2753, Australia

Y. He

College of Environmental and Natural Resource Sciences,

Zhejiang University,

Hangzhou 310029, China microbial community structure and diversity following the applications of organic wastes could help to evaluate the ecological consequences on the soil and thus to develop sound regulatory guidelines for the beneficial reuse of organic wastes in agricultural lands.

Materials and methods Soil samples were collected from recycled organics plots treated with different types and quantity of organic wastes. The field experimental treatments included control (CK, without application of any organic wastes), low amount of GTW CO (COL), GTW CL (CLL), and MSW (ML), and high amounts of GTW CO (COH), GTW CL (CLH), and MSW compost $(\mathrm{MH})$. Microbial DNA was extracted from soil samples and the $16 \mathrm{~S}$ rRNA genes were polymerase chain reaction (PCR)-amplified. The PCR products were analyzed by denaturing gradient gel electrophoresis (DGGE), cloning, and sequencing. The bacterial community structures and diversity were assessed using the DGGE profiles and clone libraries constructed from the excised DGGE bands.

Results DGGE-based analyses showed that application of the GTW CO, regardless of the amount applied, had significant negative effects on soil bacterial genotypic diversity and community structure compared with the control, while the applications of other organic wastes including the GTW CL and MSW had no clear effects. The effects of the rate of organic waste application on soil bacterial community characteristics varied with the types of organic wastes applied. Sequence-based analyses of 126 clones indicated that Proteobacteria (53.2\%) was the dominant taxa at the experimental site, followed by Actinobacteria (9.5\%), Bacteroidetes (7.9\%), Firmicutes (7.9\%), Gemmatimonadetes (5.6\%), Chloroflexi (2.4\%), Acidobacteria (1.6\%) and the unclassified group (11.9\%). 
In the $\mathrm{COH}$ treatment, Acidobacteria, Bacteroidetes, and Gemmatimonadetes were not detected; the percentages of Firmicutes, Proteobacteria, and Actinobacteria in the $\mathrm{COH}$ treatment were significantly different from those in CK. There is a significant positive correlation $(r=0.71, p=$ 0.002 ) between the $\mathrm{C} / \mathrm{N}$ ratio of organic wastes and the bacterial genotypic communities.

Discussion Both the type and the amount of GTW applied affected soil bacterial genotypic diversity and community structure. The different effects of various types of organic wastes on soil bacterial characteristics may be predicted by the differences in specific properties of organic wastes such as $\mathrm{C} / \mathrm{N}$ ratio, as evidenced by the strong and significant positive relationship between the bacterial community distance and the environmental distance of $\mathrm{C} / \mathrm{N}$ ratio. This also indicates that the $\mathrm{C} / \mathrm{N}$ ratio of GTW applied can be a major driver for the shift in the soil bacterial community.

Conclusions Our results revealed that the effects of organic wastes on soil bacterial communities varied with the types of organic wastes, and depending on the rate of application. Application of the GTW CO led to significant shifts in soil bacterial community diversity and structure. The effects of different types of organic wastes on the soil bacterial characteristics can be predicted by the differences of specific properties of organic wastes, such as the $\mathrm{C} / \mathrm{N}$ ratio. Sequence-based analyses of 126 clones indicated that Proteobacteria was the dominant taxa at the experimental site.

Recommendations and perspectives Our results have important implications for developing sound regulatory guidelines for the beneficial reuse of organic wastes, indicating that GTW $\mathrm{CO}$ and similar organic waste treatments may not be suitable for application in agricultural soils due to its significant negative effect on soil bacterial community.

Keywords Bacterial community - Bacterial diversity . Cloning and sequencing . Denaturing gradient gel electrophoresis · Organic waste $\cdot$ Soil

\section{Background, aim, and scope}

Grease trap waste (GTW) is an organic waste collected and pumped out of grease traps in wastewater drains in restaurant areas in cities to reduce the concentration of fat and suspended solids in the wastewater. Because the potential benefit of GTW as a source of organic matter and soil conditioner containing no/low amounts of metals or pathogenic organisms (Rashid and Voroney 2004), current Australian legislation permits the beneficial application of the GTW into agricultural soil. However, little is known about the influence of GTW on soil bacterial community. Soil bacteria are vital to agroecosystem health through their roles in residue decomposition and nutrient cycling and their associations with other organisms. It has long been recognized that appropriate community structure, abundant diversity, and high activity of microorganisms are significant factors to maintain the sustainability and productivity of terrestrial ecosystems (Bardgett et al. 2008; Bell et al. 2005b; Cardinale et al. 2006; Naeem and $\mathrm{Li}$ 1997). There are some reports about the positive influence of other organic amendments such as organic manures and composts on soil microbial characteristics (Enwall et al. 2007; Peacock et al. 2001; Sun et al. 2004; Zheng et al. 2008). Beneficial effects on soil bacterial communities from application of GTW may not be expected due to the presence of greater quantities of grease in GTW compared with other organic amendments. For example, application of GTW may lead to the imbalanced supply of carbon (C) and nutrients, thus affecting soil bacterial community structure and activity. In addition, high grease content in GTW may affect soil physical properties since the grease can block soil pores and form a barrier to air and water flow, leading to the lower level of $\mathrm{O}_{2}$ in soil, which may affect the bacterial community in soil. Therefore, it is necessary to evaluate the influences of application of GTW on soil bacterial community and diversity.

An understanding of the complex bacterial community in the soil environment has proven to be a challenge because of the extremely high abundance and enormous diversity of bacteria in soils (Gans et al. 2005; Torsvik et al. 1990; Xu and Chen 2006; Zhang and Xu 2008). Recent development of culture-independent molecular techniques has brought opportunities for in-depth understanding of the effects of various environmental conditions on soil bacterial community structure and diversity (Daniel 2005; Roesch et al. 2007; Torsvik et al. 1998; Zhang and Xu 2008). In this study, culture-independent molecular approaches such as soil DNA extraction, polymerase chain reaction (PCR), denaturing gradient gel electrophoresis (DGGE), cloning, and sequencing were utilized to examine the bacterial community structure and diversity in an agricultural soil following applications of GTW. Furthermore, to compare GTW with other organic wastes, municipal solid waste (MSW) compost was examined simultaneously. The aim of this study was to quantify the impacts of different types and amounts of organic wastes on the soil bacterial community and diversity. Knowledge about the shifts in microbial community structure and diversity following the applications of organic wastes could assist in appropriately evaluating the ecological consequences of application of organic wastes in the soil and thus developing sound regulatory guidelines for the beneficial reuse of organic wastes in agricultural environments. 


\section{Materials and methods}

\subsection{Site and sampling}

Soil samples were collected on 3rd March 2006, from the recycled organics plots of the Centre for Recycled Organics in Agriculture site at Menangle in South Western Sydney, Australia. The recycled organics plots consist of three blocks composed of 21 randomly distributed $2.5 \times 3 \mathrm{~m}$ plots treated with different types and amounts of organic grease wastes, with each treatment present once in each block. Two types of GTW, designated as "CO" and "CL" respectively, were used in this trial. The GTW CO was the oily fraction of the collected GTW, while the GTW CL was the fraction of the GTW that was higher in food solids; as such GTW CO had a much higher oil and grease content than the GTW CL (Table 1). The MSW is a composted organic fraction of municipal waste. The treatments include: control (CK, without application of any organic grease wastes, but with the same cultivation and management as per other treatments), the GTW CO surface applied at $100 \mathrm{t} \mathrm{ha}^{-1}$ (COL), the GTW CO surface applied at $300 \mathrm{tha}^{-1}(\mathrm{COH})$, the GTW CL surface applied at $100 \mathrm{t} \mathrm{ha}^{-1}$ (CLL), the GTW $\mathrm{CL}$ surface applied at $300 \mathrm{t} \mathrm{ha}^{-1}(\mathrm{CLH})$, MSW compost surface applied at $25 \mathrm{t} \mathrm{ha}^{-1}(\mathrm{ML})$, and MSW compost surface applied at $75 \mathrm{tha}^{-1}(\mathrm{MH})$. The application rates for GTW and MWS were based on a range of current rates recommended for the environmental safety and crop $\mathrm{N}$ requirement in NSW, Australia.

The soil type at the experiment site was a Hapludalf with silty clay loam texture, underlain by shale bedrock. The site has a typical temperate climate with cool winters and warm summers. The field site received $615 \mathrm{~mm}$ of rainfall a year, with the rainfall spread throughout most months of the year but tending to be summer dominant. Basic properties of the original soil and organic wastes are given in Table 1. The oil and grease content (Method 5520D, E), total organic C (Method 5310 A, B), and total N (Method 5310 A, B) in GTW were determined by the methods described by the American Public Health Association, American Water Works Association, Water Environment Federation (2005).
Total organic $\mathrm{C}$ and total nitrogen $(\mathrm{N})$ in MSW were measured by an Elementar Vario MAX CN analyzer. Total organic $\mathrm{C}$ and total $\mathrm{N}$ in soil were determined using a Shimadzu TOC-VcPH Analyzer. The $\mathrm{NH}_{4}{ }^{+}-\mathrm{N}$ and $\mathrm{NO}_{3}{ }^{-}-\mathrm{N}$ were extracted using $2 \mathrm{M} \mathrm{KCl}$ at a soil/extractant ratio of 1:5 and measured using a LACHAT Quickchem Automated Ion Analyzer (QuikChem Method 10-107-064-D for $\mathrm{NH}_{4}^{+}$ and QuikChem Method 10107-04-1- $\mathrm{H}$ for $\mathrm{NO}_{3}{ }^{-}$). The $\mathrm{NO}_{2}{ }^{-}-\mathrm{N}$ was not detectable. The $\mathrm{pH}$ and electrical conductivity (EC) were measured in a soil-waste/water ratio of 1:5.

For each sample plot, five subsamples of the topsoil ( 0 $10 \mathrm{~cm}$ ) were collected and mixed to form one composite sample. Each sample was placed in a sterile plastic bag, sealed, and transported to the laboratory on ice. All samples were passed through a $2.0-\mathrm{mm}$ sieve and a subsample was taken and stored at $-80^{\circ} \mathrm{C}$ for DNA analysis with the remainder stored at $4^{\circ} \mathrm{C}$ prior to chemical analysis.

\subsection{Soil DNA extraction, PCR, and DGGE analyses}

Soil DNA was extracted using the Powersoil DNA Isolation Kit (Mo Bio, Carlsbad, USA) according to the manufacturer's instruction. The $16 \mathrm{~S}$ ribosomal RNA (rRNA) gene was PCR-amplified using a protocol described previously (Ge et al. 2008b) with the extracted DNA as template and universal bacterial primers $954 \mathrm{~F}$ and 1369R (Yu and Morrison 2004). Amplicons (about 200 ng) were analyzed by DGGE using a protocol described previously (Ge et al. 2008a). In brief, the electrophoresis was run for $6 \mathrm{~h}$ at $120 \mathrm{~V}$ and a constant temperature of $60^{\circ} \mathrm{C}$ using 6\% $(w / v)$ acrylamide/bisacrylamide (37.5:1) gels containing a $30-60 \%$ linear gradient of formamide and urea $(100 \%$ denaturing solution containing $40 \%[v / v]$ formamide and $7 \mathrm{M}$ urea) in a DCode Universal Mutation Detection System (Bio-Rad Laboratories, Hercules, USA). The gels were stained with 1:10,000 SYBR nucleic acid gel stain (Invitrogen Molecular Probes, Eugene, USA) for 30 min, scanned by the Gel Documentation System, and analyzed using the software Quantity One (Bio-Rad Laboratories).

Table 1 Basic properties of the original soil and organic wastes used in this study

\begin{tabular}{lrrrcrcrc}
\hline $\begin{array}{l}\text { Soil/organic } \\
\text { waste }\end{array}$ & $\mathrm{pH}$ & \multicolumn{1}{l}{$\begin{array}{l}\mathrm{EC} \\
\left(\mu \mathrm{s} \mathrm{cm}^{-1}\right)\end{array}$} & Organic C (\%) & Total N (\%) & $\mathrm{C} / \mathrm{N}$ ratio & $\begin{array}{l}\mathrm{NO}_{3}^{-}-\mathrm{N}^{-1} \\
\left(\mathrm{mg} \mathrm{kg}^{-1}\right)\end{array}$ & $\begin{array}{l}\mathrm{NH}_{4}^{+}-\mathrm{N} \\
\left(\mathrm{mg} \mathrm{kg}^{-1}\right)\end{array}$ & $\begin{array}{l}\text { Oil and grease content } \\
\left(\mathrm{g} \mathrm{kg}^{-1}\right)\end{array}$ \\
\hline Original Soil & 5.6 & 0.06 & 2.0 & 0.18 & 11.1 & 7.6 & 6.4 & N/A \\
GTW CO & 3.3 & 250.00 & 57.0 & 0.13 & 438.5 & 0.5 & 25.0 & 670 \\
GTW CL & 4.1 & $1,000.00$ & 2.8 & 0.17 & 16.5 & 0.5 & 73.0 & 46 \\
MSW & 6.9 & 5.50 & 31.0 & 2.00 & 15.5 & 2.7 & $1,100.0$ & N/A \\
\hline
\end{tabular}

$C / N$ ratio carbon/nitrogen ratio, $E C$ electrical conductivity, $G T W$ grease trap waste, $M S W$ municipal solid waste, $N / A$ not applicable 


\subsection{Cloning and sequencing}

The gel strip of a band which could be explicitly differentiated by the eyes under UV light was excised from a DGGE gel with a $10-\mu$ sterile pipette tip and placed in a $1.5-\mathrm{ml}$ tube containing $10 \mu \mathrm{l}$ double distilled $\mathrm{H}_{2} \mathrm{O}$. Where a band with the same value was distributed among different treatments, only the most explicit band was excised and used for the following cloning and sequencing analyses. In such an instance, the sequence data were used for all bands with the same relative front value across different treatments. A second PCR was run using the excised gel DNA as template under the conditions of the first PCR. Before PCR, the $1.5-\mathrm{ml}$ tube containing specific DGGE gel band was heated to $70^{\circ} \mathrm{C}$ in water bath for 10 min until the excised gel completely dissolved in water.

The cloning experiments were carried out using the pCR2.1-TOPO vector (Invitrogen, Carlsbad, USA), following the manufacturer's instructions. Approximately $0.15 \mathrm{pmol}$ excised gel DNA amplicons were ligated into the plasmid vector pCR2.1-TOPO and transformed into competent cells (One Shot TOP10 Electrocomp Escherichia coli) in a $0.1-\mathrm{cm}$ cuvette by electroporation using MicroPulser Electroporator (Bio-Rad), followed by the addition of $0.25 \mathrm{ml}$ super optimal broth with catabolite repression and incubation at $37^{\circ} \mathrm{C}$ for $1 \mathrm{~h}$ with agitation $(200 \mathrm{rpm})$ in an incubator. Thirtymicroliter dilutions were plated onto the Luria-Bertani (LB) plates with ampicillin/X-Gal and incubated overnight $(16 \mathrm{~h})$ at $37^{\circ} \mathrm{C}$. About ten white colonies for each excised gel sample were randomly selected, picked out, and cultured using $\mathrm{LB}$ broth overnight at $37^{\circ} \mathrm{C}$ with agitation $(200 \mathrm{rpm})$ in an incubator. The randomly selected positive clones (five clones for each excised gel sample) were sequenced on a 3130xl Genetic Analyzer (Applied Biosystems, Foster, USA) using BigDye Terminator v3.1 Ready Reaction Cycle Sequencing kit (Applied Biosystems).

The DNA sequences obtained were manually proofed, corrected, and edited to start and end with the corresponding primer nucleotide (using reverse complement transform if necessary) using Sequencer 4.7 (Gene Codes, Ann Arbor, USA). Possible chimeric sequences were checked using the Bellerophon chimera detection program (Huber et al. 2004). Valid sequences were identified with the taxonomic affiliation using the program Classifier in the Ribosomal Database Project II. The unique 16S rRNA gene sequences were deposited in the GenBank database and assigned accession numbers FJ262600 to FJ262716.

2.4 Comparison of bacterial genotypic diversity and community structure

The bacterial genotypic diversity and community structure were determined from DGGE profile data. DGGE is a commonly used DNA-based community fingerprinting method for detecting the high-throughput differences between microbial communities (Reche et al. 2005). Members of different species may share the same DGGE band (Ge et al. 2008b). Although DGGE patterns provide a different taxonomic resolution than species, it is a consistent measure of community composition and diversity (Bell et al. 2005a). Any one species consistently produces the same band in the DGGE gel and different DGGE bands always derive from either one or several species. Therefore, differences between the fingerprinting patterns would directly reflect changes in the community composition.

For bacterial genotypic diversity estimation, each detected band in DGGE gel was defined as an operational taxonomic unit (OTU) according to their relative front values, and the number of bands was defined as the genotypic richness of each sample (Bell et al. 2005a). The pixel intensity for each band was detected by Quantity One software and was expressed as the relative abundance $\left(p_{i}\right)$ (Reche et al. 2005). Shannon index $\left(H^{\prime}\right)$ and evenness index $(J)$, the most widely used diversity indices, were calculated using the richness and relative abundance data based on the following equation:

$H^{\prime}=-\sum p_{i} \ln \left(p_{i}\right)$

$J=H^{\prime} / H_{\max }$

where $p_{i}=n_{i} / N, H_{\max }=\ln S, n_{i}$ is the abundance of the $i$ th OTU, $N$ is the total abundance of all OTUs in the sample, and $S$ is the number of OTUs. Richness, Shannon index, and evenness index were selected to reflect the bacterial diversity properties. One-way analysis of variance (ANOVA) was used to determine significance of differences between different diversity indices.

Principal coordinates analysis (PCoA) was conducted to compare the molecular fingerprints in the bacterial communities between experimental treatments using DGGEbased dataset. PCoA is an unconstrained ordination technique to examine the ecological distances between different communities (Ramette 2007). An arrangement of samples with their distances in the PCoA graph matched as closely as possible those in the ecological distance matrix can be found using the PCoA. PCoA is more appropriate than principal components analysis because of its flexibility to various distances such as Bray-Curtis distance which is a better index to reflect the dissimilarity of communities. Bacterial genotypic community structure data were logtransformed before PCoA. ANOVA and PCoA analyses were carried out using the "R" statistical software (Venables and Ripley 2002). 
2.5 Linking the properties of organic wastes to the bacterial genotypic community structure

The Mantel test was conducted to determine which properties of the organic wastes have important effects on the soil bacterial community by examining the Pearson correlation between the environmental distance of the organic wastes properties and the ecological distance of the bacterial genotypic community with 500 permutations. The investigated properties of organic wastes include $\mathrm{pH}$, electrical conductivity (EC), total organic $\mathrm{C}$, total $\mathrm{N}, \mathrm{C} / \mathrm{N}$ ratio, $\mathrm{NO}_{3}{ }^{-}-\mathrm{N}$, and $\mathrm{NH}_{4}{ }^{-}-\mathrm{N}$. Before calculating the environmental distance (Euclidean distance), the properties of the organic amendments were standardized by dividing the correspondent properties of the original soil and then were log-transformed. The ecological distance (Bray-Curtis distance) of the bacterial genotypic community used in the Mantel test was the same as that used in PCoA. The calculations of distance and the Mantel test were carried out using the "R" statistical software (Venables and Ripley 2002).

\section{Results}

\subsection{Bacterial genotypic diversity}

The DGGE band patterns of the experimental treatments are shown in Fig. 1. In total, 58 different band types (OTUs) were detected on the DGGE gel. The bacterial DGGE-based genotypic diversity characteristics (including richness, Shannon index, and evenness index) are summarized in Table 2.

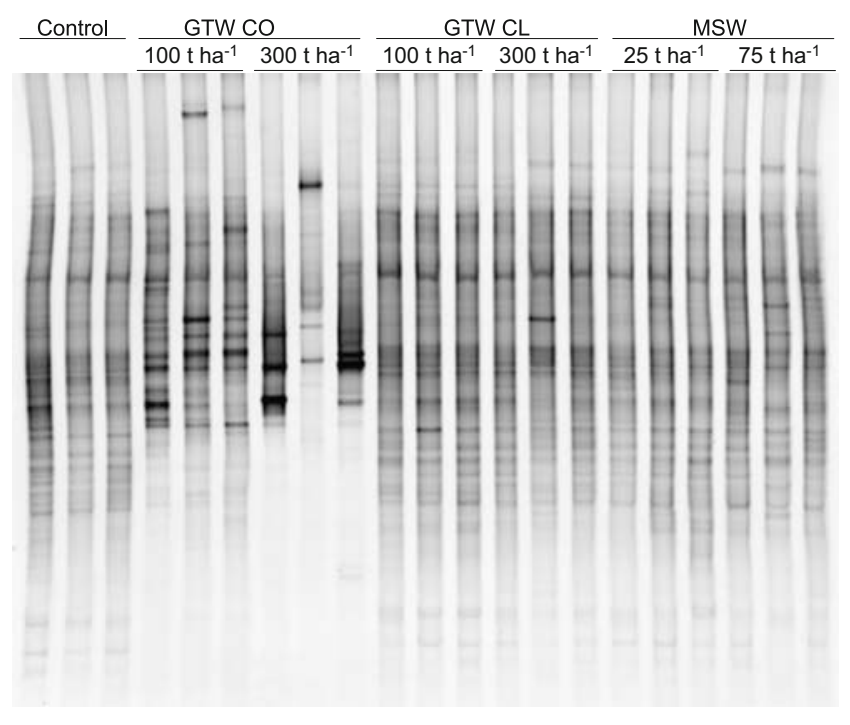

Fig. 1 Bacterial communities in different organic waste treatments as determined by PCR-DGGE of $16 \mathrm{~S}$ rRNA genes. $M S W$ municipal solid waste, $G T W$ grease trap waste
Table 2 Genotypic diversity properties of soil bacteria in different organic waste treatments using DGGE bands pattern data

\begin{tabular}{lccc}
\hline Treatment & Richness & Shannon $\left(H^{\prime}\right)$ & Evenness $(J)$ \\
\hline CK & $32 \pm 4^{\mathrm{c}}$ & $3.40 \pm 0.10^{\mathrm{c}}$ & $0.98 \pm 0.01^{\mathrm{bc}}$ \\
$\mathrm{COL}$ & $19 \pm 2^{\mathrm{b}}$ & $2.88 \pm 0.12^{\mathrm{b}}$ & $0.97 \pm 0.01^{\mathrm{b}}$ \\
$\mathrm{COH}$ & $10 \pm 2^{\mathrm{a}}$ & $2.23 \pm 0.14^{\mathrm{a}}$ & $0.96 \pm 0.01^{\mathrm{a}}$ \\
$\mathrm{CLL}$ & $29 \pm 1^{\mathrm{c}}$ & $3.30 \pm 0.02^{\mathrm{c}}$ & $0.98 \pm 0.00^{\mathrm{bc}}$ \\
$\mathrm{CLH}$ & $30 \pm 7^{\mathrm{c}}$ & $3.31 \pm 0.23^{\mathrm{c}}$ & $0.98 \pm 0.00^{\mathrm{bc}}$ \\
$\mathrm{ML}$ & $32 \pm 5^{\mathrm{c}}$ & $3.40 \pm 0.16^{\mathrm{c}}$ & $0.98 \pm 0.00^{\mathrm{c}}$ \\
$\mathrm{MH}$ & $30 \pm 3^{\mathrm{c}}$ & $3.34 \pm 0.12^{\mathrm{c}}$ & $0.98 \pm 0.00^{\mathrm{c}}$ \\
\hline
\end{tabular}

Mean $\pm \mathrm{SD}(n=3)$. Values within the same column followed by the same letter do not differ at $p<0.05$

$C K$ control (no addition of grease wastes, but with the same cultivation and management as per other treatments), $C O L$ GTW CO $\left(100 \mathrm{t} \mathrm{ha}^{-1}\right), \mathrm{COH}$ GTW CO $\left(300 \mathrm{t} \mathrm{ha}^{-1}\right)$, CLL GTW CL $(100 \mathrm{t}$ $\left.\mathrm{ha}^{-1}\right), C L H$ GTW CL (300 t ha $\left.{ }^{-1}\right), M L$ MSW compost $\left(25 \mathrm{t} \mathrm{ha}^{-1}\right)$, $M H$ MSW compost $\left(75 \mathrm{t} \mathrm{ha}^{-1}\right), G T W$ grease trap waste, MSW municipal solid waste

The values of richness, Shannon index, and evenness index in the $\mathrm{COH}$ treatment had the lowest value and were significantly lower than those in the other treatments including the $\mathrm{CK}$ treatment. The values of richness, Shannon index, and evenness index in the COL treatment were significantly higher than those in the $\mathrm{COH}$ treatment but significantly lower than those in the $\mathrm{CK}$ treatment (except the evenness index). The values of richness, Shannon index, and evenness index were not significantly different among the CK, CLL, CLH, ML, and MH treatments.

\subsection{Bacterial community structure}

The results of PCoA are illustrated in Fig. 2. Each point in the PCoA graph represents a sample associated with a treatment. The near distance of two points in the graph indicates a small ecological distance between the community compositions. The eigenvalues of the first two axes were 0.044 and 0.026 and their contributions to the total variance were $41.24 \%$ and $24.05 \%$, which express how much variance is shown on each axis. Therefore, the total variance which can be explained by the two-dimensional PCoA graph was $65.29 \%$.

In the two-dimensional PCoA graph (see Fig. 2), the first principal coordinate well differentiated the GTW CO treatments $(\mathrm{COL}$ and $\mathrm{COH})$ from the other treatments. These results indicated that the overall bacterial community structure of the GTW CO treatments was significantly different from those of $\mathrm{CK}$ and other organic waste treatments. The $\mathrm{COL}$ and $\mathrm{COH}$ were subsequently separated by the second principal coordinate, suggesting that the application of different amounts of GTW CO also caused differences in 


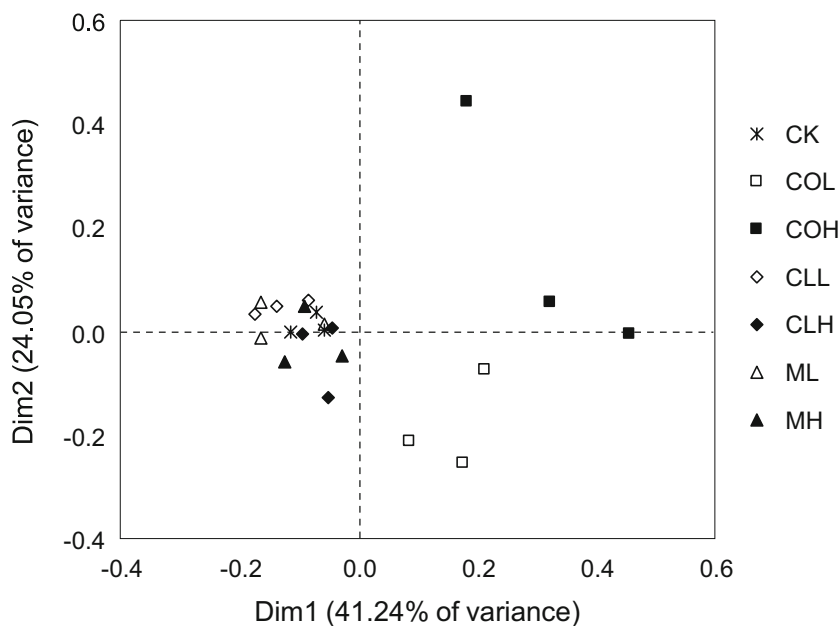

Fig. 2 Principal coordinates analysis of soil bacterial DGGE band patterns in different organic wastes treatments. $C K$ control (without application of any grease wastes, but with the same cultivation and management as per other treatments), COL GTW CO $\left(100 \mathrm{t} \mathrm{ha}^{-1}\right)$, COH GTW CO $\left(300 \mathrm{t} \mathrm{ha}^{-1}\right), C L L$ GTW CL $\left(100 \mathrm{t} \mathrm{ha}^{-1}\right)$, CLH GTW CL (300 t ha $\left.{ }^{-1}\right), M L$ MSW compost $\left(25 \mathrm{t} \mathrm{ha}^{-1}\right), M H$ MSW compost $\left(75 \mathrm{t} \mathrm{ha}^{-1}\right), G T W$ grease trap waste, $M S W$ municipal solid waste

the bacterial genotypic community. The samples from CK, CLL, CLH, ML, and MH treatments were more closely clustered, suggesting that their overall bacterial community structures were more similar to each other.

The results of the Mantel test of the Pearson correlation between the bacterial community and specific properties of organic wastes are summarized in Table 3. The results show that there is a significant positive correlation $(r=0.71, p=$ 0.002 ) between the $\mathrm{C} / \mathrm{N}$ ratio of organic wastes and the bacterial genotypic communities. For $\mathrm{pH}$ and total organic $\mathrm{C}$, despite significance level of the correlation $(p<0.05)$, there is a large scatter of observations and the correlation is low. It seems that there are no significant correlations between the other investigated properties of organic wastes and the bacterial genotypic communities.

\subsection{Differences of bacterial phylum among different treatments}

The explicit bands were excised from the DGGE gel. Different sequences were retrieved from one band by the cloning method. These bands seemed to contain more than two different DNA fragments. For example, there are 117 unique sequences in a total of 126 sequences retrieved from 26 excised bands. All retrieved sequences were classified into seven taxa at the phylum level, or as unclassified bacteria. Proteobacteria (53.2\%) was the dominant taxonomic group, followed by unclassified bacteria (11.9\%), Actinobacteria (9.5\%), Bacteroidetes (7.9\%), Firmicutes $(7.9 \%)$, Gemmatimonadetes (5.6\%), Chloroflexi (2.4\%), and Acidobacteria $(1.6 \%)$. All seven bacterial taxa were observed in every
Table 3 Mantel test of the Pearson correlation between the bacterial community and specific properties of organic wastes

\begin{tabular}{lll}
\hline Property & $r$ & $P$ \\
\hline $\mathrm{C} / \mathrm{N}$ & 0.71 & $0.002^{* *}$ \\
$\mathrm{pH}$ & 0.26 & $0.002^{* *}$ \\
Organic C & 0.15 & $0.008^{* *}$ \\
Total N & -0.04 & 0.522 \\
$\mathrm{NH}_{4}{ }^{+}-\mathrm{N}$ & -0.07 & 0.764 \\
$\mathrm{NO}_{3}{ }^{-} \mathrm{N}$ & -0.10 & 0.802 \\
$\mathrm{EC}$ & -0.14 & 0.940 \\
\hline
\end{tabular}

$C / N$ carbon/nitrogen ratio, $E C$ electrical conductivity

${ }^{* *}$ Correlation is significant at the 0.01 level.

treatment except $\mathrm{COH}$ in which Acidobacteria, Bacteroidetes, and Gemmatimonadetes were absent (Table 4).

The results of ANOVA of the percentage of different bacterial taxa among different treatments are summarized in Table 4. It was noted that the percentage of clone sequences of all the eight bacterial taxa in treatments of CLL, CLH, ML, and MH showed no significant differences compared against $\mathrm{CK}$, while some bacterial taxa were significantly affected by the $\mathrm{COL}$ and $\mathrm{COH}$ treatments compared with the $\mathrm{CK}$ treatment. For example, the percentages of Bacteroidetes in the COL were significantly higher than that in CK; the percentages of Firmicutes and Proteobacteria in $\mathrm{COH}$ were significantly higher than those in the CK; and the percentages of Acidobacteria, Actinobacteria, Bacteroidetes, and Gemmatimonadetes in $\mathrm{COH}$ was significantly lower than those in CK. The percentages of Acidobacteria, Bacteroidetes, and Gemmatimonadetes in COL were significantly higher than those in $\mathrm{COH}$, while Firmicutes in $\mathrm{COL}$ was significantly lower than that in $\mathrm{COH}$.

\section{Discussion}

4.1 Effects of organic wastes on soil bacterial community

Our results revealed that the effects of organic wastes on soil bacterial communities varied predominately with the types of organic wastes. This is supported by the observation that the applications of the GTW CO has distinct negative effects on soil bacterial genotypic diversity and community structure compared with those in the CK; meanwhile, the applications of other organic wastes types including the GTW CL and MSW had no negative effects. The negative effect of the GTW CO on soil bacterial genotypic diversity and community structure may be due to the high concentration of oil and grease contained in this type of GTW (see Table 1), which led to the distinct behavior of the GTW $\mathrm{CO}$ in influencing soil bacterial 


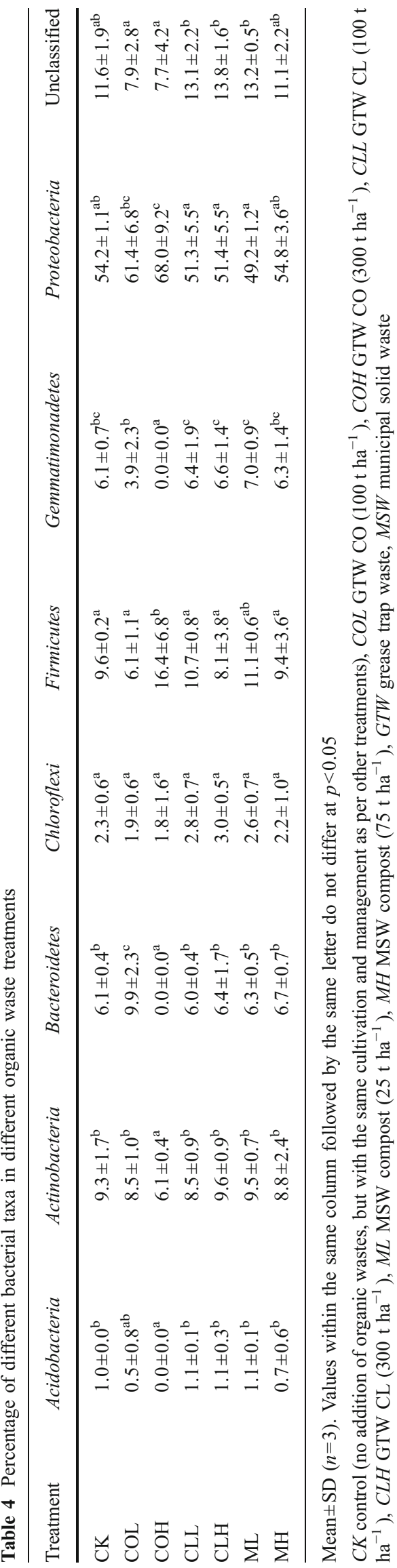

communities compared with other organic wastes examined in this study and reported previously (Enwall et al. 2007; Peacock et al. 2001; Ros et al. 2006). It is interesting to note that the application of the GTW CL showed no negative effect on soil bacterial genotypic diversity and community structure. As these two GTWs are of different origins, we speculate that differences in basic properties of these GTWs may be responsible for their different behaviors in influencing soil bacterial communities. However, applications of the GTW CL and MSW have similar effects on soil bacterial communities although they exhibit differences in most basic soil properties. Therefore, we hypothesize that there might be some key soil properties which play a predominant role in driving the shift in soil bacterial communities. The Mantel test of the Pearson correlation indicated that there were significant correlations between the $\mathrm{C} / \mathrm{N}$ ratio, $\mathrm{pH}$, and organic $\mathrm{C}$ of organic wastes and the soil bacterial communities. In particular, the $\mathrm{C} / \mathrm{N}$ ratio of organic wastes, with a correlation coefficient of 0.71 with bacterial community distance $(p=0.002$; see Table 3), has been identified as a key property which is responsible for the differences in soil bacterial community diversity and structure among the different types of organic wastes. No significant differences in the soil bacterial community found between the GTW CL and MSW treatments may be due to the fact that they have similar $\mathrm{C} / \mathrm{N}$ ratios despite of the differences in the other properties (see Table 1). In contrast, the differences in soil bacterial community diversity and structure between the GTW CO and the GTW CL could be attributed to the significantly greater $\mathrm{C} / \mathrm{N}$ ratio in the GTW $\mathrm{CO}(\mathrm{C} / \mathrm{N}$ ratio 438$)$ compared with the GTW $\mathrm{CL}(\mathrm{C} / \mathrm{N}$ ratio 16.5 ; see Table 1$)$. The distinct effects of the GTW CO and the GTW CL with different $\mathrm{C} / \mathrm{N}$ ratios on soil microbial community may be due to the imbalance in $\mathrm{C}$ and $\mathrm{N}$ supply to microbial communities. Moreover, the greater amounts of oil and grease (high in C) found in the GTW CO than the GTW CL (see Table 1) may also affect soil physical properties by blocking soil pores, forming a barrier to air and water flow and affecting the $\mathrm{O}_{2}$ level in soil and consequently contribute to the shift in the soil bacterial community.

Our results also showed that the effects of the rate of application on soil bacterial community characteristics varied with types of organic wastes. For example, the different application rates of the GTW CO had significant effects on the soil bacterial genotypic diversity and community structure, while the different application rates of the GTW CL and MSW had no significant effects. With the increased rate of the GTW CO application, the soil bacterial community was further depauperate and the soil bacterial genotypic diversity significantly decreased.

The GTW may prove beneficial as source of organic matter to soil, while containing nil or minimal metals or 
pathogenic organism contaminants which are major public concerns associated with the agricultural application of other types of organic wastes such as sewage sludge and manure (Bååth et al. 1998; Saison et al. 2006; Witter et al. 2000). Unlike sewage sludge and many other organic amendments which can contain significant amounts of $\mathrm{N}$, phosphorus, potassium, or other nutrient materials, GTW contains large amounts of readily degradable $\mathrm{C}$ compounds but very little of the nutrients required for plant or microbial growth (Rashid and Voroney 2004); thus, this may lead to an imbalance in $\mathrm{C}$ and other essential nutrients creating negative effects on soil bacterial community. Evidently, our results have major implications for developing sound regulatory guidelines for the use of GTW in agriculture by indicating which types of GTW are unsuitable for application in the agricultural soils due to their significant negative effects on soil bacterial community.

4.2 Soil 16S rRNA gene clone library and sequence-based analyses

The strategy of whole-community DNA extraction, cloning, and sequencing, following PCR-DGGE gel excision or direct cloning and sequencing after PCR amplification, was useful in gaining an insight into the soil microbial communities (He et al. 2005, 2006). In this work, except for exploring the overall patterns of soil bacterial community, DGGE was also used as a strategy to screen and decrease the number of clones for sequencing (Ge et al. 2008b). The sequence data were used to examine the overall community composition in the field experimental site and explore the potential composition differences of soil bacterial communities in soils applied with different types and amounts of organic wastes. The Chaol and ACE methods were used to estimate the total bacterial species richness for our samples. The Chao 1 method and the ACE method yielded estimates of 498 and 496 total species at 0.03 Jukes-Cantor evolutionary distances, respectively. There were 84 clones that differed by more than 0.03 Jukes-Cantor evolutionary distances in our overall clone libraries, and therefore, we conservatively estimate that we sampled approximately $17 \%$ of the total species richness in this study.

For the overall community composition at the experimental site, $88.1 \%$ of the clones sequenced were classified in seven major taxa: Proteobacteria (53.2\%), Actinobacteria (9.5\%), Bacteroidetes (7.9\%), Firmicutes (7.9\%), Gemmatimonadetes (5.6\%), Chloroflexi (2.4\%), and Acidobacteria $(1.6 \%)$. This result deviates from that observed in an agroecosystem treated with the manure in the Netherlands where Acidobacteria, Proteobacteria, Nitrospira, Cyanobacteria, and green sulfur bacteria were the predominant bacterial taxa (Smit et al. 2001). This may reflect the dissimilarities of the two agroecosystems because of spatial distance and soil types. Some recent reports have demonstrated that spatial distance and soil types may be the major factor contributing to the differences of soil bacterial diversity and community composition (Bundy et al. 2002; Ge et al. 2008a; Girvan et al. 2003). Janssen (2006) assigned a total of 2,920 sequences from 21 soil bacterial libraries (including forest, pasture, and farm soil) and classified them by the Classifier program of RDP to identify the distribution of soil bacterial taxa. It was found that the most abundant phylum was Proteobacteria (10 77\%), followed by Acidobacteria (5-46\%), Actinobacteria (0-34\%), Verrucomicrobia (0-21\%), Bacteroidetes (0$18 \%)$, Chloroflexi (0-16\%), Planctomycetes (0-8\%), Firmicutes (0-8\%), and Gemmatimonadetes (0-4\%; Janssen 2006). While most of the bacterial taxa observed in our study were in the range of the overall distribution of the bacterial phyla, it is noted that Acidobacteria and Gemmatimonadetes were present in different percentages in our study. This may further highlight the variations of bacterial composition among the different sites.

The phylum level distribution of clone sequences in each treatment of this study showed that: the $\mathrm{COH}$ treatment was significantly different from the $\mathrm{CK}$; the percentages of Firmicutes and Proteobacteria in $\mathrm{COH}$ were significantly higher than those in the $\mathrm{CK}$; the percentage of Actinobacteria in $\mathrm{COH}$ was significantly lower than those in the CK; and Acidobacteria, Bacteroidetes, and Gemmatimonadetes were not detected in the $\mathrm{COH}$ treatment. These results further confirm that the application of the GTW CO at a higher rate led to shifts in soil bacterial community diversity and structure. Some work has reported that the relative variation of Proteobacteria and Acidobacteria might reflect the nutrient status in the soils tested (Smit et al. 2001; Sun et al. 2004). From our study, the increased percentage of Proteobacteria and the decreased percentage of Acidobacteria observed in soils applied with the GTW CO may indicate that the relative variation of Proteobacteria and Acidobacteria could serve as a good indicator of the changes in the environmental condition or disturbance in the soils.

\section{Conclusions}

Our results revealed that the effects of organic wastes on soil bacterial communities varied predominantly with the types of organic wastes. Application of the GTW CO had led to significant shifts in soil bacterial community diversity and structure. The effects of different types of organic wastes on the soil bacterial characteristics may be predicted by the differences of specific properties of organic wastes, particularly the $\mathrm{C} / \mathrm{N}$ ratio. Sequence-based analyses of 126 clones indicated that Proteobacteria was the dominant taxa at the experimental site. 


\section{Recommendations and perspectives}

Our results have important implications for developing sound regulatory guidelines for the beneficial reuse of organic wastes, indicating that GTW CO may not be appropriate for application in agricultural soils because of its significant negative effect on soil bacterial community.

Acknowledgments This research was jointly supported by the Australian Research Council, the Natural Science Foundation of China, the Chinese Academy of Sciences, and a New South Wales Government Treasury Enhancement Grant. The assistances of staff for soil sampling and data collecting from both Chinese and Australian sides are sincerely appreciated. The authors would also like to thank Ms. Marijke Heenan for her lab assistance and proofreading of this manuscript.

\section{References}

American Public Health Association (APHA), American Water Works Association, Water Environment Federation (2005) Standard Methods for the Examination of Water and Wastewater. 21st edition. American Public Health Association, Washington DC. Pp1368

Bååth E, Díaz-Raviña M, Frostegård Å, Campbell CD (1998) Effect of metal-rich sludge amendments on the soil microbial community. Appl Environ Microbiol 64:238-245

Bardgett RD, Freeman C, Ostle NJ (2008) Microbial contributions to climate change through carbon cycle feedbacks. ISME J 2:805-814

Bell T, Ager D, Song J-I, Newman JA, Thompson IP, Lilley AK, van der Gast CJ (2005a) Larger islands house more bacterial taxa. Science 308:1884

Bell T, Newman JA, Silverman BW, Turner SL, Lilley AK (2005b) The contribution of species richness and composition to bacterial services. Nature 436:1157-1160

Bundy JG, Paton GI, Campbell CD (2002) Microbial communities in different soil types do not converge after diesel contamination. J Appl Microbiol 92:276-288

Cardinale BJ, Srivastava DS, Duffy JE, Wright JP, Downing AL, Sankaran M, Jouseau C (2006) Effects of biodiversity on the functioning of trophic groups and ecosystems. Nature 443:989-992

Daniel R (2005) The metagenomics of soil. Nat Rev Micro 3:470-478

Enwall K, Nyberg K, Bertilsson S, Cederlund H, Stenstrom J, Hallin S (2007) Long-term impact of fertilization on activity and composition of bacterial communities and metabolic guilds in agricultural soil. Soil Biol Biochem 39:106-115

Gans J, Wolinsky M, Dunbar J (2005) Computational improvements reveal great bacterial diversity and high metal toxicity in soil. Science 309:1387-1390

Ge Y, He J-Z, Zhu Y-G, Zhang J-B, Xu Z, Zhang L-M, Zheng Y-M (2008a) Differences in soil bacterial diversity: driven by contemporary disturbances or historical contingencies? ISME J 2:254-264

Ge Y, Zhang J-B, Zhang L-M, Yang M, He J-Z (2008b) Long-term fertilization regimes affect bacterial community structure and diversity of an agricultural soil in northern China. J Soils Sediments 8:43-50

Girvan MS, Bullimore J, Pretty JN, Osborn AM, Ball AS (2003) Soil type is the primary determinant of the composition of the total and active bacterial communities in arable soils. Appl Environ Microbiol 69:1800-1809

He JZ, Xu ZH, Hughes J (2005) Analyses of soil fungal communities in adjacent natural forest and hoop pine plantation ecosystems of subtropical Australia using molecular approaches based on 18S rRNA genes. FEMS Microbiol Lett 247:91-100
He JZ, Xu ZH, Hughes J (2006) Molecular bacterial diversity of a forest soil under residue management regimes in subtropical Australia. FEMS Microbiol Ecol 55:38-47

Huber T, Faulkner G, Hugenholtz P (2004) Bellerophon: a program to detect chimeric sequences in multiple sequence alignments. Bioinformatics 20:2317-2319

Janssen PH (2006) Identifying the dominant soil bacterial taxa in libraries of $16 \mathrm{~S}$ rRNA and 16S rRNA genes. Appl Environ Microbiol 72:1719-1728

Naeem S, Li S (1997) Biodiversity enhances ecosystem reliability. Nature 390:507-509

Peacock AD, Mullen MD, Ringelberg DB, Tyler DD, Hedrick DB, Gale PM, White DC (2001) Soil microbial community responses to dairy manure or ammonium nitrate applications. Soil Biol Biochem 33:1011-1019

Ramette A (2007) Multivariate analyses in microbial ecology. FEMS Microbiol Ecol 62:142-160

Rashid MT, Voroney RP (2004) Land application of oily food waste and corn production on amended soils. Agron J 96:997-1004

Reche I, Pulido-Villena E, Morales-Baquero R, Casamayor EO (2005) Does ecosystem size determine aquatic bacterial richness? Ecology 86:1715-1722

Roesch LFW, Fulthorpe RR, Riva A, Casella G, Hadwin AKM, Kent AD, Daroub SH, Camargo FAO, Farmerie WG, Triplett EW (2007) Pyrosequencing enumerates and contrasts soil microbial diversity. ISME J 1:283-290

Ros M, Pascual JA, Garcia C, Hernandez MT, Insam H (2006) Hydrolase activities, microbial biomass and bacterial community in a soil after long-term amendment with different composts. Soil Biol Biochem 38:3443-3452

Saison C, Degrange V, Oliver R, Millard P, Commeaux C, Montange D, Le Roux X (2006) Alteration and resilience of the soil microbial community following compost amendment: effects of compost level and compost-borne microbial community. Environ Microbiol 8:247-257

Smit E, Leeflang P, Gommans S, van den Broek J, van Mil S, Wernars K (2001) Diversity and seasonal fluctuations of the dominant members of the bacterial soil community in a wheat field as determined by cultivation and molecular methods. Appl Environ Microbiol 67:2284-2291

Sun HY, Deng SP, Raun WR (2004) Bacterial community structure and diversity in a century-old manure-treated agroecosystem. Appl Environ Microbiol 70:5868-5874

Torsvik V, Salte K, Sørheim R, Goksøyr J (1990) Comparison of phenotypic diversity and DNA heterogeneity in a population of soil bacteria. Appl Environ Microbiol 56:776-781

Torsvik V, Daae FL, Sandaa R-A, Øvreås L (1998) Novel techniques for analysing microbial diversity in natural and perturbed environments. J Biotechnol 64:53-62

Venables WN, Ripley BD (2002) Modern applied statistics with S. Springer, Berlin

Witter E, Gong P, Bååth E, Marstorp H (2000) A study of the structure and metal tolerance of the soil microbiual community six years after cessation of sewage sludge. Environ Toxicol Chem 19:1983-1991

$\mathrm{Xu} \mathrm{Z}$, Chen CR (2006) Fingerprinting global climate change and forest management within rhizosphere carbon and nutrient cycling processes. Environ Sci Pollut Res 13:293-298

Yu Z, Morrison M (2004) Comparisons of different hypervariable regions of rrs genes for use in fingerprinting of microbial communities by PCR-denaturing gradient gel electrophoresis. Appl Environ Microbiol 70:4800-4806

Zhang L, Xu Z (2008) Assessing bacterial diversity in soil. J Soils Sediments 8:379-388

Zheng Y, Zhang L-M, Zheng Y-M, Di H, He J-Z (2008) Abundance and community composition of methanotrophs in a Chinese paddy soil under long-term fertilization practices. J Soils Sediments 8:406-414 